\title{
内耳に打ける神経情報伝達
}

\author{
陣内 自治・小池 靖夫・福井 清*

\section{Glutamatergic Neurotransmission in the Inner Ear}

\author{
Osamu Jinnouchi and Yasuo Koike \\ (The University of Tokushima School of Medicine) \\ Kiyoshi Fukui \\ (Institute for Enzyme Research, The University of Tokushima)
}

\begin{abstract}
Fast excitatory synaptic transmission in the inner ear has been proposed to be mediated by an excitatory amino acid, possibly L-glutamate, and its receptors. Previous studies have revealed that certain types of ionotropic glutamate receptors are expressed in various combinations of subtypes in the cochlea and vestibule. Other studies have suggested that some glutamate receptors may have non-neural functions, such as cell differentiation and migration. Recently the glutamate receptor $\delta$ subfamily has been identified, although little is known about its physiological characteristics thus far. Since 1997 it has been known that the $\delta 1$ subunit is highly expressed in hair cells of auditory and vestibular systems, which suggests that the $\delta 1$ subunit may play an important functional role in these systems. The expression of NMDA receptor mRNA in spiral ganglion cells has also been demonstrated, suggesting involvement of the NMDA receptor in neurotransmission in the inner ear. In search of coagonists of the NMDA receptor other than glycine, D-serine has been found to be present in mammalian central nervous systems and is regarded as a possible neuro-modulator of the NMDA receptor. We have demonstrated the gene expression of D-amino acid oxidase (DAO) in the rat temporal bone using RT-PCR analysis. This observation suggests that D-serine, which is the substrate of DAO, may exist in the inner ear and may modulate the neurotransmission of NMDA receptor subunit NR1.
\end{abstract}

Key words : neurotransmission, ionotroic glutamate receptor, $\delta 1$ subunit, D-amino acid oxidase

はじめに

内耳蝸牛における速い情報伝達機構は, 主としてグル タミン酸とイオンチャンネル型のグルタミン酸受容体に よって構築され，また脳幹の上オリーブ核から外有毛細 胞に投射する遠心性神経伝達にはアセチルコリンと GABA が関与することが示唆されている. 生化学的, 電気生理学的, 薬理学的な手法によってグルタミン酸や 関連するアミノ酸が内耳有毛細胞一らせん神経節シナプ

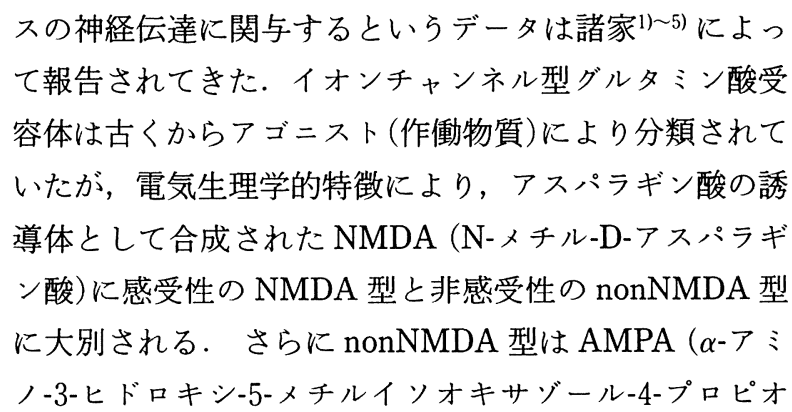


表 1 イオンチャンネル型グルタミン酸受容体の分類

\begin{tabular}{|c|c|c|}
\hline 類 & アゴニスト & サブニニット \\
\hline $\mathrm{AMPA}^{*}$ 型 & AMPA & GluR1-4 ( $\alpha 1-4)$ \\
\hline $\mathrm{KA}^{* *}$ 型 & カイ二ン酸 & $\begin{array}{r}\text { GluR5-7 ( } \beta 1-3) \\
\text { KA1, } 2(\gamma 1,2)\end{array}$ \\
\hline $\mathrm{NMDA}^{* * *}$ 型 & NMDA & $\begin{array}{c}\mathrm{NR} 1(\zeta 1) \\
\mathrm{NR} 2_{\mathrm{A}-\mathrm{D}}(\varepsilon 1-4)\end{array}$ \\
\hline$\delta$ 型 & （不明） & $\delta 1,2$ \\
\hline \multicolumn{3}{|c|}{$\begin{array}{l}\text { * alpha-amino-3-hydroxy-5-methylisooxazole-4-propionic } \\
\text { acid }\end{array}$} \\
\hline
\end{tabular}

ン酸)型と KA (カイニン酸; kainate)型に分類されてい

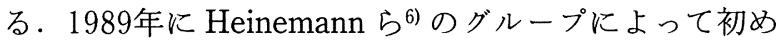
てグルタミン酸受容体がクローニングされて以来, 従来 のアゴニストによる分類に対応した受容体分子がさまざ まなサブタイプとともにクローニングされた(表 1 ). nonNMDA 型受容体は $\mathrm{Na}^{+}$と $\mathrm{K}^{+}$を透過させ, 主とし て速い興奮性シナプス伝達を担っている。一方 NMDA 型は $\mathrm{Na}^{+}, \mathrm{K}^{+}, \mathrm{Ca}^{2+}$ に高い透過性を示し, $\mathrm{Mg}^{2+}$ から 電位依存的阻害を受けるなどシナプスの可塑性に重要な 役割を持っていると考觉られている。ここではグルタミ ン酸受容体を中心とした耳科学領域に执ける神経伝達機 構の構筑と最新の話題につき述べることとする.

\section{内耳におけるグルタミン酸受容体の機能と局在}

1. non-NMDA 型受容体

non-NMDA 型のサブュニットは AMPA 型 (GluR1-4), $\mathrm{KA}$ 型 (GluR5-7, KA1，2)がクローニングされている. 内耳有毛細胞一らせん神経節シナプスに括ける AMPA 型, $\mathrm{KA}$ 型の介在も電気生理学的 (278), 免疫細胞化学的 $飞^{3)}$ ，また In Situ Hybridization (以下 ISH) 法や9)10), PCR 法で11) それぞれ示されてきた，通常はnon-NMDA 型受容体の構成は GluR2 サブュニットを含んだ組み合 わせで複合体が形成され，その組み合わせによって透過 するイオンの選択性が異なっていると考えられている. さらに蝸牛の発達段階に㧊ける nonNMDA 型受容体の 発現パターンをISH 法でみると，らせん板縁の線維細 胞など非神経組織にも発現を認め, グルタミン酸受容体 サブニニットが膜レセプターとして組織分化, 器官形成 といった non-neuronal functionを持つ可能性も考㝋ら
れている12)。 また土井13i は alternative splicing によって GluR3 の塩基配列より少し短くなった mRNA が内耳に 特異的に発現していることを報告し，このバリアントの 受容体は電気生理学的には inhibitory subunit である可 能性を推察している.このように non-NMDA 型受容体 は神経伝達のみならず未だ解明されていない側面は多い。

2. NMDA 型受容体

1980年代はじめには内耳有毛細胞一らせん神経節シナ プスに括ける NMDA 型受容体の介在は否定的であった。 しかし NMDA 型受容体が海馬に和ける長期増強 (Longterm Potentiation ; LTP) や小脳沉括ける長期抑圧 (Longterm Depression； LTD) に深く関与することや，脱分 極するにはグリシン1415) や D-セリン16117)を必要とした り，高頻度刺激のような強い入力がシナプスに必要であ

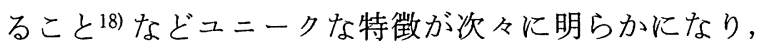
内耳に招いても研究がなされた. Puel ら ${ }^{19}$ はNMDA 型受容体の阻害物質を蝸牛に潅流し，音刺激が強い場合 (110 dB SPL， $8 \mathrm{kHz}$ トーンバースト)には，潅流しない 時よりも CAP の振幅が約40\%低下寸ることを報告した。 NMDA 型受容体は分子生物学的には通常 NR1 サブュ ニットと他の NMDA 型サブュニット $\left(\mathrm{NR} 2_{\mathrm{A}-\mathrm{D}}\right)$ の組み 合わせでチャンネルを構成していると考えられているが， Safieddine ら ${ }^{10)}$ と Kuriyama ら ${ }^{20)}$ はNR1がらせん神経 節に発現していることをISH 法でそれぞれ示している. しかし nonNMDA 型と NMDA 型の発現は両者ともに, らせん神経節，前庭神経節のニューロン，グリアでみら れて打り，内耳有毛細胞に特異的な発現はみられていな い.

\section{3. $\delta$ 型受容体}

第 4 番目のサブファミリーとしては $\delta$ 型 $(\delta 1, \delta 2)$ が 同定されている.このサブファミリーは分子構造からイ オンチャンネル型に分類されているが，他のイオンチャ ンネル型受容体とは一次構造上アミノ酸レベルでのホモ ロジーも低く，阻害物質が未同定なことなど不明な点が 多い受容体であった。最近になって $\delta 2$ 型はマウスでは 胎生15日より認められ，発達段階の小脳で発現し，成熟 期には小脳プルキンエ細胞の dendritic spine に限局し

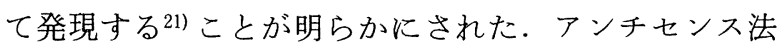
（翻訳開始部位を含んだアンチセンス鎖のオリゴヌクレ オチドを培養細胞に添加しセンス鎖 RNA からの翻訳を 阻害する方法)を用いて $\delta 2$ 型レセプターの発現を抑制し た実験系では小脳に拈ける長期抑圧現象が阻害され22), 
小脳の高次機能に㧊ける $\delta 2$ 型レセプターの重要性が強 く示唆されている.さらに $\delta 2$ 型ミュータントマウスで は小脳での協調運動障害が出現し, 前庭代償が認められ ないことも報告された ${ }^{23)}$. このことから平衡機能との関 与が推測され, 北原ら ${ }^{24)}$ は一側の内耳を破壊したラッ トでは小脳のプルキンェ細胞層で $\delta 2$ 型レセプターの mRNA の発現が減少することを明らかにした. Kashiwabuchi ら ${ }^{25)}$ によれば $\delta 2$ 型は小脳平行線維-プルキンエ細 胞間シナプスの長期抑圧現象に深く関与することから， 北原らは内耳破壊後の対側前庭と小脳は $\delta 2$ 型の発現を 抑制することにより小脳のシナプス伝導効率を変化させ， 前庭代償を誘導すると推察している。

1997年に Safieddine ら ${ }^{26)}$ は $\delta 1$ 型が蝸牛の内有毛細胞 と前庭有毛細胞に強く発現していることをISH で報告 した。外有毛細胞に発現はなく，小脳に発現していた $\delta$ 2 型は内耳に発現していなかった。 このことは蝸牛内有 毛細胞と外有毛細胞が明らかに機能的違いをもつことを 示唆する. $\delta$ 型サブファミリーは $\delta 1$ 型が内耳, $\delta 2$ 型が 小脳と $2 つ の$ 組織においてサブュニットは異なるものの 聴覚平衡機能に重要な役割を持つレセプターサブフ マミ リーである可能性がでてきた．今後はアゴニストの発見 やレセプター複合体としての発現様式など， $\delta$ 型レセプ ターの持つ特質をつまびらかにすることが必要であると 思われる.

\section{NMDA 型受容体とコアゴニスト}

NMDA 型受容体は常時 active でない上, activateさ れにくいといら特徵をもつ受容体であり, 小脳の長期抑 圧や海馬の記憶など神経の可塑性に深く関与していると 考えられている. また最近では NMDA 型受容体のコア ゴニスト (coagonist) といら概念 ${ }^{27)}$ が定着しつつある.

現在コアゴニストの候補としてはグリシンと D-セリン が注目を集めているが，グリンンょりも D-セリンの方

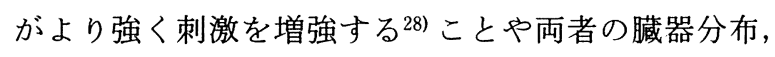
生理的濃度 ${ }^{29)}$ を考虑するとグリシンの生理的濃度より, D-セリンの生理的濃度の方がコアゴニストとしての活 性としては effective であると考えられる。また Snyderのグループ30) は大脳, 小脳, 脳幹に拈いて NMDA 型受容体の NR1 と D-セリンの組織の局在には 高い相関性があることを示している.

$\mathrm{D}$-アミノ酸は老化に伴い血液中で濃度が上昇するこ とが知られ ${ }^{31)}$, 神経機能の老化と D-アミノ酸の関連も
示唆されてきた. D-アミノ酸のらちD-セリンは中枢神 経系のシナプス32)やグリア細胞33) で産生されると考兄 られ，通常はグリア細胞内に留まり，グルタミン酸によ る神経刺激によりシナプス間隙に放出される ${ }^{34)}$. D-セリ ンはシナプスの NR1 に存在するグリシン結合部位に結 合 ${ }^{14)}$ し，神経刺激を増強する．このグルタミン酸によ る刺激を増強する作用によってグルタミン酸による神経 傷害性を強めていると考兄られている。

D-セリンは D-アミノ酸を特異的に酸化する D-アミノ 酸酸化酵素 (EC 1.4.3.3；DAO)により代謝をらける. この酵素は腎臓，小脳でその発現が強く認められるが (図 1 a)我々はラットに拈いて内耳組織を含んだ側頭骨 から，DAOの mRNA の発現をRT-PCR 法で確認した (図 1 b).1995年に Kuriyama ら ${ }^{20)}$ はNR1がらせん神 経節ニューロンで発現していることを報告したが，NR1 と D-セリンの局在がよく相関する30) ことと合わせて考 えれば，らせん神経節のサテライトグリアにも DAO が 存在する可能性が示唆される.グリア細胞は中枢神経系 でD-セリンのスカベンジャーとしての働きをもつとさ れているが蝸牛に打いてもらせん神経節のサテライトグ リアが同様にD-セリンの放出，スカベンジを行ってい ると推定される。また蝸牛神経核すべて(背側核, 前腹 側核, 後腹側核)にNR1 の mRNA が発現しておうり, 上 行性聴覚伝導路の興奮性シナプスにおいても NMDA 型 受容体の関与が示唆されている.

D-アミノ酸 1 分子は DAOにより代謝される際，1分 子の $\mathrm{H}_{2} \mathrm{O}_{2}$ を生じ, 周辺の細胞を障害することは腎臓で は知られていた ${ }^{35)}$. 最近では D-アミノ酸代謝で産生さ れる $\mathrm{H}_{2} \mathrm{O}_{2}$ は脳腫瘍に対する遺伝子治療に応用できる可 能があるほどの Reactive Oxygen Species であることが 示されている36). 加齢に伴って体内の D-セリン濃度が 上昇し, それにより $\mathrm{H}_{2} \mathrm{O}_{2}$ 産生が徐々に増加し, 細胞内 で処理できない量に達すれば, 神経細胞や周辺組織に傷 害的に働く可能性がある. 現在我々は大脳皮質由来のグ リア初代培養細胞を用いて neuro-modurator として位 置づけられるDAO の遺伝子発現とその調節機構を解析 し ${ }^{37)}, \mathrm{D}$-七リンならびに DAO の生理的意義の解明を目指 している. 今後 D-セリンが蝸牛や聴覚伝導路の NMDA 型受容体でも機能する因子であるといら鬽惑的な仮説を 検討していきたいと考えている. 


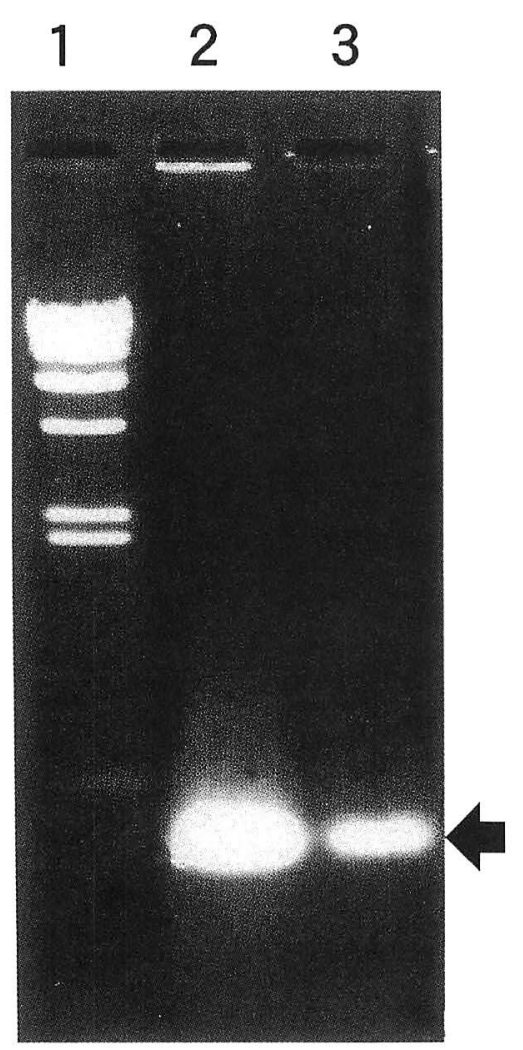

a

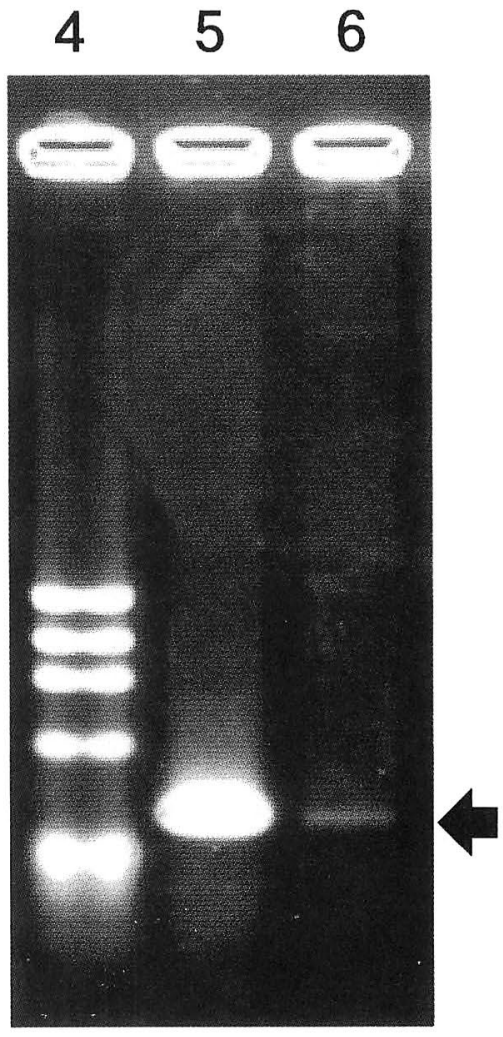

b

図 1 RT-PCR を用いたD-アミ，酸酸化酵素(DAO) の遗伝子発現

a ）ラット小脑, 腎蔵に批る DAO 遺伝子の発現

Lane $1: \lambda /$ Hind III $5 \mu 1$

$2:$ 小脳 (mRNA $1 \mu \mathrm{g})$,

3 : 腎臓 (mRNA $0.1 \mu \mathrm{g})$

b ）ラット側頭骨組織に和ける DAO 遺伝子の発現

Lane $4: \phi \times 174 /$ Hae III $4 \mu \mathrm{l}$

5 : 腎臓 (total RNA $5 \mu \mathrm{g}$ ),

$6:$ 側頭骨組織 (total RNA $5 \mu \mathrm{g}$ )

括弧内はテンプレート量.

矢印は塩基配列から予想される 398 bp のバンドを示す。

おわりに

神経伝達をアッセイする方法として神経耳科学領域は in vivo で比較的容易に定量性が得られる特性がある.

しかし内耳組織は側頭骨に内包され，構成する細胞が少 ない割に細胞の種類が多いことが研究の大きな障壁にな ってきた．最近では分子生物学的新技術の導入や組織培 養の工夫により以前は検出困難であった遺伝情報のメッ セージや形態も明らかになり，内耳外有毛細胞の運動 能38)や，蝸牛における虚血時のグルタミン酸放出の測 定とそれに伴う聴力域值の上昇 ${ }^{39)}$ な゙次々に新たな知
見がもたらされている.今後はより複雑な生理現象が分 子レベルで発現される機能によって説明でさるよらに研 究が進展することが期待される.

\section{参考文献}

1) Bledsoe SC, Bobbin RP and Puel JL : Neurotransmission in the inner ear. Physiology of the Ear. pp 385 406, Raven Press, NY, 1988.

2) Altschuler RA, Sheridan CE, Horn JW, et al : Immunocytochemical localization of glutamate immunoreac- 
tivity in the guinea pig cochlea. Hear Res $42: 167 \sim 174$, 1988.

3 ) Kuriyama H, Jenkins $\mathrm{O}$ and Altschuler RA : Immunocytochemical localization of AMPA selective glutamate receptor subunits in the rat cochlea. Hearing Research $80: 233 \sim 240,1994$.

4) Gleich O, Johnstone BM and Robertson D : Effects of Lglutamate on auditory afferent activity in view of its proposed excitatory transmitter role in the mammalia cochlea. Hear Res 45 : 295 311, 1990.

5 ) Hunter C, Doi K and Wenthold RJ : Neurotranmission in the auditory system. Otolaryngol Clinic North. Am 25 : $1027 \sim 1052,1992$.

6) Hollmann $M$, Hartley $M$ and Heinemann $\mathrm{S}: \mathrm{Ca}^{2+}$ permeability of KA-AMPA gated glutamate receptor channel depends on subunit composition. Science $252: 851 \sim$ 853, 1991.

7 ) Jenison GL, Winbery S and Bobbin RP : Comparative actions of quisqualate and N-methyl-D-Aspartate, excitatory amino acid agonists on guinea pig cochlea. Comp Biochem Physiol 84 : 385 389, 1985.

8 ) Jenison GL and Bobbin RP : Quisqulate excites spiral ganglion neurons of guinea pig. Hear Res $20: 261 \sim 265$, 1986.

9) Ryan AF, Watts AG and Simmons DM : Preservation of mRNA during in situ hybridization in the cochlea. Hear Res $56:$ 148 152, 1991 .

10) Safieddine $S$ and Eybalin $M$ : Co-expression of NMDA and AMPA/kainate receptor mRNAs in cochlear neurones. Neuroreport $3:$ 1145 1148, 1992.

11) Doi $K$, Hunter $C$ and Wenthold RJ : DNA amplification of subunits of the AMPA selective glutamate receptor family of the rat and guinea pig cochlea. pp 19, Abstr Assoc Res Otolaryngol, NJ, 1992.

12) Luo L, Brumm D and Ryan AF : Distribution of nonNMDA glutamate receptor mRNAs in the developing rat cochlea. J Comp Neurol 361 : 372 382, 1995.

13）土井勝美 : 内耳 Glutamate - Acetylcholine - GABA receptor の分子構造. ブレインサイエンス 1(俣野彰三編). 17 ２9頁, 厚生社, 大阪, 1994.

14) Johnson JW and Ascher $P$ : Glycine potentiates the NMDA response in cultured mouse brain neurons. Nature $325: 529 \sim 531,1987$.

15) Williams $\mathrm{K}$, Chao J, Kashiwaguchi $\mathrm{K}$, et al : Activation of N-methyl-D-aspartate receptors by glycine. Mol Pharmacol $50: 701 \sim 708,1996$.

16) Kleckner NW and Dingledine $R$ : Requirement for glycine in activation of NMDA-receptors expressed in xenopus oocytes. Science $241: 835 \sim 837,1988$.

17) Wood PL, Emmett MR and Rao TS : In vivo moduration of the N-methyl-D-aspartate receptor complex by $\mathrm{D}$ serine. J Neurochem 53 : 979 981, 1989.

18) Collingridge GI, Herron $\mathrm{CE}$ and Lester RAJ : Frequencydependent N-methyl-D-aspartate receptor-mediated synaptic transmission in rat hippocampus. J Physiol $399: 301 \sim$ $312,1988$.

19) Puel JL, Ladrech $S$ and Eybalin $M$ : Electrophysiological evidence for the presence of NMDA receptors in the guinea pig cochlea. Hear Res 51 : 255 264, 1991.

20) Kuriyama $\mathrm{H}$, Albin RL and Altschuler RA : Expression of NMDA-receptor mRNA in the rat cochlea. Hear Res 69 : 215 220, 1993

21) Takayama C, Nakagawa $S$, Watanabe $M$, et al : Developmental changes in expression and distribution of the glutamate receptor channel delta 2 subunit according to the purkinje cell maturation. Brain Res Dev Brain Res $92: 147 \sim 155,1996$.

22) Jeromin A, Huganir RL and Linden DJ : Suppression of the glutamate receptor delta 2 subunit produces a specific impairment in cerebellar long-term depression. J Neurophysiol $76: 3578 \sim 3583,1996$

23) Funabiki $K$, Mishina $M$ and Hirano $T$ : Retarded vestibular compensation in mutant mice deficient in delta 2 glutamate receptor subunit. Neuroreport $7: 189 \sim 192$, 1995.

24）北原 糺, 武田憲昭, 久保 武, 他：分子生物学的手法に よる前庭代償分子機構の解明 一Differential Display 法を 用いて一. 日耳鼻 $101: 37 \sim 43,1998$.

25) Kashiwabuchi N, Ikeda K, Araki K, et al : Impairment of motor coordination, purkinje cell synapse formation, and cerebellar long-term depression in gluR delta 2 mutant mice. Cell $81: 245 \sim 252,1995$.

26) Safieddine $\mathrm{S}$ and Wenthold RJ : The glutamate receptor subunit $\delta 1$ is highly expressed in hair cells of the auditory and vestibular systems. J Neuroscience $17: 7523 \sim 7531$, 1997.

27) Kuryatov A, Laube B, Betz H, et al : Mutational analysis of the glycine-binding site of the NMDA receptor. Neuron $12: 1291 \sim 1300,1994$.

28) Matsui $T$, Sekiguchi M, Hashimoto A, et al : Functional comparison of $\mathrm{D}$-serine and glycine in rodents ; the effect on cloned NMDA receptors and the extracellular concentration. J Neurochem 65 : 454 458, 1995.

29) Hashimoto A, Nishikawa $T$, Takahashi $K$, et al : Endogenous $\mathrm{D}$-serine in rat brain; $\mathrm{N}$-methyl-D-aspartate receptor-related distribution and aging. J Neurochem 
$60: 783 \sim 786,1993$.

30) Schell MJ, Brady JRO, Snyder SH, et al : D-Serine as a neuromodulator; regional and developmental localizations in rat brain glia resemble NMDA receptors. J Neuroscience $17: 1604 \sim 1615,1997$.

31) Nagata $Y$, Akino $T$, Ohno K, et al : Free D-amino acids in human plasma in relation to senescence and renal diseases. Clin Science 73 : 105 108, 1987.

32) Dunlop DS and Neidle A : The origin and turnover of Dserine in brain. Biochem Biophys Res Commun $235: 26 \sim$ 30, 1997.

33) Sato K, Yoshida S, Fujiwara K, et al : Glycine cleavage system in astrocytes. Brain Res $567: 64 \sim 70,1991$.

34) Schell MJ, Molliver ME and Snyder SH : D-serine, an endogenous synaptic modulator; localization to astrocytes and glutamate-stimulated release. Proc Natl Acad Sci USA 92 : 3948 3952, 1995.

35) Carone FA and Ganote CE:D-serine nephrotoxicity. Arch Pathol $99:$ 658 662, 1975.

36) Stegmann L, Yoseph $\mathrm{OB}$ and Ross $\mathrm{BD}$ : Induction of cytotoxic oxidative stress by D-alanine in brain tumor cells expressing rhodotorulagracilis $\mathrm{D}$-amino acid oxidase; a cancer gene therapy strategy. Hum Gene Ther $9: 185 \sim$ 193, 1998.

37) Fukui K, Kanamori $T$, Jinnouchi $O$, et al : Tissue specific expression of the $\mathrm{D}$-amino acid oxidase gene. Flavins and Flavoproteins (Stevenson KJ Ed). pp 199 202, Univ of Calgary Press, Calgary, 1996.

38）大西純夫，山下敏夫：内耳蝸牛外有毛細胞とイオンチャン ネル．ブレインサイエンス 1 (俣野彰三編). 39〜47頁, 厚 生社, 大阪, 1994.

39) Hakuba N, Gyo K, Yanagihara N, et al : Efflux of glutamate into the perilymph of the cochlea following transient ischemia in the gerbil. Neurosci Lett $230: 67 \sim 71$, 1997.

$\left(\begin{array}{l}\text { 別刷請求先 : 陣内自治 } \\ \text { 干770-8503 徳島市蔵本町 3 丁目 18-5 } \\ \text { 徳島大学医学部耳鼻咽喉科学教室 }\end{array}\right)$ 